\title{
Gestational protein-energy malnutrition affects the composition of developing skins of rat fetuses and their dams
}

\author{
BY TAKASHI MIWA ${ }^{1}$, HIROMU SHOJI', MOSHE SOLOMONOW', \\ MALEKTAJ YAZDANI ${ }^{2}$ AND TETSUO NAKAMOTO ${ }^{3}$ \\ Departments of ${ }^{1}$ Orthopedic Surgery, ${ }^{2}$ Pediatrics, and ${ }^{3}$ Physiology, Louisiana State \\ University Medical Center, 1542 Tulane Avenue, New Orleans, Louisiana 70112, USA
}

(Received 11 December 1986 - Accepted 9 March 1987)

\begin{abstract}
1. Various biochemical variables of the skins of rat dams and their fetuses in which protein-energy malnutrition was induced during pregnancy were analysed.

2. One group of dams was fed on a $200 \mathrm{~g}$ protein $/ \mathrm{kg}$ diet as a control and the other was fed on a $60 \mathrm{~g}$ protein/ $\mathrm{kg}$ diet as an experimental group. Each group of dams was fed from day 13 of gestation until day 22 .

3. Water, protein and hexosamine concentrations of the fetal skins in the malnourished group were greater than those in the control group, whereas in the dams' skins, protein concentration was greater in the malnourished group than in the control group.

4. Extractability of collagen with neutral salt and pepsin showed no difference between the groups in the skins of fetuses and dams. The content of type III collagen in the fetal skin did not differ between the groups, but was increased in the malnourished dams' skins compared with that of the control group.

5. The present study showed that protein-energy malnutrition during pregnancy significantly affects the metabolism of the skin in both fetuses and their dams. Furthermore, the skins of fetuses and dams are structurally altered in different ways by this nutritional stress.
\end{abstract}

Although malnutrition has been known to affect collagen metabolism, the effects of protein deficiency on skin collagen metabolism remain controversial. Some workers report the loss of an appreciable amount of collagen as a result of a low-protein diet (Anasuya \& Narasinga Rao, 1970; Dawson \& Milne, 1978), whereas others claim an increase (Cabak et al. 1963). In addition, most of these studies on skin collagen metabolism were conducted using young and adult animals. The effects of protein restriction during pregnancy are reported to be less severe to the fetuses because of the protective role of the placenta (Nowak \& Munro, 1977). The prenatal period, however, is also the most critical to the growth and development of many organs (Zeman, 1970; Nakamoto et al. 1983), and slight changes of the nutritional state during gestation might profoundly affect tissue formation.

Many pregnant women may have a protein intake that is less than the recommended daily allowance (Zlatnik \& Burmeister, 1983). In one study, $38 \%$ of the subjects in a lowincome group had a protein intake of less than $50 \mathrm{~g} / \mathrm{d} ; 18 \%$ in a high-income group had an intake below this level ((US) Department of Health, Education and Welfare, 1972). Thus, malnutrition during pregnancy is not a rarity in industrialized nations. In the present study the effect of protein-energy malnutrition during pregnancy on collagen metabolism of growing rat fetuses and their dams was investigated and the dermal structural changes, if any, which resulted were also examined.

\section{MATERIALS AND METHODS}

Ten timed-pregnant Sprague-Dawley rats were purchased from the breeder (Holtzman Co., Madison, WI). On day 13 of gestation (sperm-positive day as day 1), they were randomly divided into two groups. One group $(n 6)$ was fed on a $60 \mathrm{~g}$ protein $/ \mathrm{kg}$ diet and the other $(n 4)$ was fed on a $200 \mathrm{~g}$ protein $/ \mathrm{kg}$ diet until day 22 . The dietary composition is 
Table 1. Components of diet $(\mathrm{g} / \mathrm{kg})$

\begin{tabular}{lcc}
\hline \hline & \multicolumn{2}{c}{ Diet } \\
\cline { 2 - 3 } Ingredients & Low protein & Control \\
\hline Casein & 60 & 200 \\
Glucose & 267 & 192 \\
Sucrose & 172 & 177 \\
Dextrin & 261 & 192 \\
Cellulose & 35 & 35 \\
Mineral mix* & 40 & 40 \\
Vitamin mix $\dagger$ & 10 & 10 \\
Maize oil (Mazola $\left.{ }^{\infty}\right)$ & 150 & 150 \\
Choline chloride $(500 \mathrm{~g} / \mathrm{l} ; \mathrm{ml})$ & 4 & 4 \\
Methionine & 1 & - \\
\hline
\end{tabular}

* Rogers-Harper mineral mix (Teklad Test Diet; Teklad, Madison, WI)

† AIN vitamin mixture 76 (ICN Pharmaceuticals Inc., Cleveland, OH)

shown in Table 1. All the diets were made isoenergetic by adding glucose, sucrose, and dextrin. The food intake of the dams was measured daily. On day 22, dams were anaesthetized with diethyl ether and fetuses were removed by caesarean section. Fetuses were immediately decapitated and their skins were removed and shaved free of fat. The skins of all fetuses delivered from each dam were pooled. The dams' skins were also removed and shaved free of hair and fat. The skin weight of each fetus and dam was recorded.

After being dried and weighed to determine water content, these skins were minced and homogenized. The amount of protein was measured by the method of Lowry et al. (1951). Dried skin, about $10 \mathrm{mg}$ of each sample, was partially hydrolysed in $2 \mathrm{M}$-hydrochloric acid at $110^{\circ}$ for $12 \mathrm{~h}$. After the samples were evaporated and redissolved in distilled water, the amount of hexosamine was determined by the method of Gatt \& Berman (1966). The remaining portion was rehydrolysed in $6 \mathrm{M}-\mathrm{HCl}$ at $130^{\circ}$ for $3 \mathrm{~h}$. Hydroxyproline was assayed on the remaining portion by the method of Woessner (1961).

For each group approximately $2 \mathrm{~g}$ dried skin were used for sequential extraction of collagen with $1.0 \mathrm{M}$-sodium chloride and $0.5 \mathrm{M}$-acetic acid with pepsin according to the modified method of Bornstein \& Piez (1966). Each stage of extraction was carried out for $48 \mathrm{~h}$ at $4^{\circ}$. Pepsin $(200 \mathrm{mg}$ ) was dissolved in $200 \mathrm{ml} 0.5 \mathrm{M}$-acetic acid. Hydroxyproline was measured to determine the collagen content in a portion of extract at each stage of extraction. After lyophilization SDS gel electrophoresis was done on the pepsin-soluble collagen according to a modified method of Syke's interrupted gel electrophoresis (Sykes et al. 1971). The gel was scanned at $560 \mathrm{~nm}$ using a German Densitometer ACD15. The content of type III collagen was calculated using the standard curve of a sequential mixture of standard type I and type III collagen prepared from placenta, as described previously (Shoji et al. 1983). The results were evaluated by Student's $t$ test, with $P<0.05$ considered statistically significant.

\section{RESULTS}

On day 22, the average body-weights of dams fed on either a $200 \mathrm{~g}$ protein $/ \mathrm{kg}$ diet or a $60 \mathrm{~g}$ protein $/ \mathrm{kg}$ diet were 455 (SD 11) and 332 (SD 40 ) g respectively. The daily increases in body-weights of the dams in the control group and malnourished group were 11.8 (SD 0.2) 
Table 2. Comparison of biochemical measurements in skin of malnourished ( $60 \mathrm{~g}$ casein) $\mathrm{kg}$ diet) and control (200 $\mathrm{g}$ casein $/ \mathrm{kg}$ diet) dams and their fetuses

(Mean values and standard deviations)

\begin{tabular}{|c|c|c|c|c|c|c|c|c|c|}
\hline \multirow{2}{*}{$\begin{array}{l}\text { Dietary casein } \\
(\mathrm{g} / \mathrm{kg})\end{array}$} & \multirow[b]{2}{*}{$n$} & \multicolumn{2}{|c|}{$\begin{array}{l}\text { Water content } \\
(\mathrm{g} / \mathrm{kg})\end{array}$} & \multicolumn{2}{|c|}{$\begin{array}{l}\text { Protein } \\
(\mu \mathrm{g} / \mathrm{mg}) \dagger\end{array}$} & \multicolumn{2}{|c|}{$\begin{array}{l}\text { Hexosamine } \\
(\mu \mathrm{g} / \mathrm{mg})\end{array}$} & \multicolumn{2}{|c|}{$\begin{array}{c}\text { Hydroxyproline } \\
(\mu \mathrm{g} / \mathrm{mg})\end{array}$} \\
\hline & & Mean & SD & Mean & SD & Mean & SD & Mean & So \\
\hline \multicolumn{10}{|l|}{ Fetuses } \\
\hline 60 & 6 & $903^{*}$ & 3.0 & $776 \cdot 2^{*}$ & $30 \cdot 6$ & $6.88^{* *}$ & 0.73 & $13 \cdot 50$ & 1.06 \\
\hline 200 & 4 & 890 & $4 \cdot 5$ & $668 \cdot 4$ & 35.8 & $4 \cdot 92$ & 0.69 & $13 \cdot 46$ & 0.57 \\
\hline \multicolumn{10}{|l|}{ Dams } \\
\hline 60 & 6 & 597 & $14-8$ & $185 \cdot 4^{*}$ & 16.8 & $3 \cdot 20$ & $0 \cdot 30$ & $85 \cdot 3$ & $2 \cdot 78$ \\
\hline 200 & 4 & 612 & $8 \cdot 2$ & 133.4 & $15 \cdot 4$ & 3.48 & 0.87 & $83 \cdot 2$ & $1 \cdot 36$ \\
\hline
\end{tabular}

Mean values were significantly different from control values: ${ }^{*} P<0.05,{ }^{* *} P<0.01$.

$\uparrow$ Measured on a dry skin basis.

Table 3. Biochemical variables per total skin mass for fetuses from malnourished $(60 \mathrm{~g}$ casein $/ \mathrm{kg}$ diet) and control dams (200 $\mathrm{g}$ casein $/ \mathrm{kg}$ diet)

(Mean values and standard deviations)

\begin{tabular}{|c|c|c|c|c|c|c|c|}
\hline \multirow{2}{*}{$\begin{array}{l}\text { Dietary casein } \\
(\mathrm{g} / \mathrm{kg})\end{array}$} & \multirow[b]{2}{*}{$n$} & \multicolumn{2}{|c|}{ Protein (mg) } & \multicolumn{2}{|c|}{ Hexosamine $(\mu \mathrm{g})$} & \multicolumn{2}{|c|}{ Hydroxyproline $(\mu \mathrm{g})$} \\
\hline & & Mean & SD & Mean & SD & Mean & SD \\
\hline 60 & 6 & $17 \cdot 67^{*}$ & 1.86 & $124 \cdot 8^{*}$ & $13 \cdot 2$ & $314 \cdot 9 * *$ & 21.9 \\
\hline 200 & 4 & $25 \cdot 00$ & $1 \cdot 38$ & 165.9 & $13 \cdot 1$ & $503 \cdot 7$ & $9 \cdot 9$ \\
\hline
\end{tabular}

Mean values were significantly different from control values: ${ }^{*} P<0.05,{ }^{* *} P<0.01$.

and 5.1 (SD 0.7) g respectively. The average body-weight of the fetuses in the malnourished group (5.08 (SD 0.77) g) was less than that of the controls $(6.85$ (SD 0.36$) \mathrm{g} ; P<0.05)$. The total dry skin weight of each fetus was less in the malnourished group (21.89 (SD 3.34) $\mathrm{mg}$ ) than in the control group (37.46 (SD 2.12) $\mathrm{mg} ; P<0.05$ ).

Water, protein and hexosamine concentrations of the fetal skins were greater in the malnourished group than in the control group $(P<0.05)$ (Table 2). Hydroxyproline concentration did not differ between the two groups. Skins of dams from the malnourished group also had a higher protein concentration than those of the controls $(P<0.05)$. Protein, hexosamine and hydroxyproline concentrations were significantly lower in the malnourished group than in the control group when calculated on the basis of total skin mass of each fetus $(P<0.05)$ (Table 3$)$.

Extractability of collagen from the skins of both fetuses and dams showed no statistically significant difference for each portion of the extract, between malnourished and control groups; however, extractability of collagen in the neutral salt in the fetal skins in both groups was greater than that of the dams $(P<0.05)$ (Table 4$)$. On the other hand, extractability of collagen of fetal skin in the pepsin-soluble portion for both groups was less than that of the dams' skins $(P<0.05)$. The pepsin-insoluble portion was about the same for the skins of the fetuses and dams in the malnourished and control groups.

Concentrations of type III collagen in fetal skins did not differ between the two groups, 
Table 4. Extractability ( $\mathrm{mg} / \mathrm{g}$ total collagen) of collagen at each stage of extraction from skin of malnourished $(60 \mathrm{~g}$ casein $/ \mathrm{kg})$ and control $(200 \mathrm{~g}$ casein $/ \mathrm{kg})$ dams and their fetuses

(Mean values and standard deviations)

\begin{tabular}{|c|c|c|c|c|c|c|c|c|c|}
\hline \multirow{3}{*}{$\begin{array}{l}\text { Dietary casein } \\
(\mathrm{g} / \mathrm{kg})\end{array}$} & \multirow[b]{3}{*}{$n$} & \multicolumn{6}{|c|}{ Extractability (mg/g total collagen) } & \multirow{2}{*}{\multicolumn{2}{|c|}{$\begin{array}{c}\text { Content of } \\
\text { type III collagen } \\
\text { (mg/g total collagen) }\end{array}$}} \\
\hline & & \multicolumn{2}{|c|}{ Neutral salt } & \multicolumn{2}{|c|}{ Pepsin-soluble } & \multicolumn{2}{|c|}{ Pepsin-insoluble } & & \\
\hline & & Mean & SD & Mean & SD & Mean & _. SD & Mean & SD \\
\hline \multicolumn{10}{|l|}{ Fetuses } \\
\hline 60 & 6 & $165^{*}$ & 34 & $779^{*}$ & 24 & 50 & 18 & $239^{*}$ & $14 \cdot 2$ \\
\hline 200 & 4 & $128^{*}$ & 48 & $805^{*}$ & 42 & 63 & 10 & $245^{*}$ & $25 \cdot 0$ \\
\hline \multicolumn{10}{|l|}{ Dams } \\
\hline 60 & 6 & 21 & 10 & 931 & 9 & 45 & 11 & $112 \dagger$ & $8 \cdot 4$ \\
\hline 200 & 4 & 25 & 3 & 907 & 7 & 62 & 3 & 70 & $11 \cdot 4$ \\
\hline
\end{tabular}

* Mean values were significantly different from those of the dams on the corresponding diet $(P<0-05)$.

$\dagger$ Mean value was significantly different from the control value $(P<0-01)$.

whereas in the dams' skins, this was greater in the malnourished group than in the control group $(P<0.01)$. Type III collagen concentrations of the fetal skins of both groups were greater than those of the dams.

\section{DISCUSSION}

Because the dams that were given the protein-deficient diet consumed less food than the controls in the present study, they experienced deficiencies in protein as well as in energy. How malnutrition affects collagen and non-collagenous protein of the skin is still uncertain. Skin collagen and non-collagenous protein in the young or adult malnourished rat have been reported to be both increased (Cabak et al. 1963) and decreased (Dawson \& Milne, 1978; Anasuya \& Narasinga Rao, 1970). The present findings relating to skins of the developing fetus and their dams under gestational protein-energy malnutrition differ from those of Taniguchi et al. (1984), although the experimental conditions also differ.

The water content in fat-free body tissue of rats continuously decreases as animals mature (Spray \& Widdowson, 1950). In the present study, the water content of the fetal skin was higher in the malnourished group than in the controls. This possibly suggests that the fetal skin in the malnourished group was immature compared with that of the controls. We previously reported that the skins from protein-energy malnourished newborns had a lower water content than did those of control newborns, whereas in the lactating dams, the water content was greater in the malnourished group than in the control (Taniguchi et al. 1984). The present results may indicate that the effects of gestational protein-energy malnutrition on water content of the skins of fetuses and their dams differ considerably from those on skins of newborn sucklings and their lactating dams.

The rate of collagen accumulation during the early neonatal period had been reported to be a function only of collagen synthesis (Jefferey et al. 1985). Protein-energy malnutrition during pregnancy did not appear to affect the rate of collagen synthesis of fetal skin, as is shown by the similarity of hydroxyproline concentration between the two groups. The protein content of the total skin of each fetus was less in the malnourished group than in the control group. On the other hand, protein concentration in the 
malnourished group of the fetuses was greater than that of the controls. This increase in the protein concentration in the malnourished group seems to be due to the production of glycosaminoglycans since hexosamine concentration of the malnourished group was increased, whereas collagen concentration did not differ between groups.

In contrast to the findings for fetal skins, the compositional changes of the variables measured in the dams' skins showed only a slight difference between the groups, suggesting that the dams' skins could be more resistant to the stress of protein-energy malnutrition than those of the fetuses.

When extractability of collagen was expressed as $\mathrm{mg} / \mathrm{g}$ total collagen, no statistically significant difference was found, at each step of extraction, between the groups in the skins of fetuses and their dams. In the malnourished group, however, extractability of collagen in fetal skins by neutral salt tended to be greater than that in the controls. Thus, cross-link formation of fetal skin may possibly be decreased by malnutrition.

The finding that the neutral-salt extract was much greater for the fetal skins of both groups than in that of the dams' skins suggests that the larger portion of collagen in the newborns is less stable than that of the dams, regardless of malnutrition. The finding of smaller pepsin-soluble and pepsin-insoluble portions in the fetal skins of the malnourished group may indicate that the stability of collagen of fetal skin could have been reduced by gestational protein-energy malnutrition. In addition, since increases in pepsin-insoluble collagen represents the ageing process of collagen (Miyahara et al. 1982), the decreased amount of insoluble collagen in the malnourished group may suggest the immaturity of the collagen of these skins.

In our previous study on the effect of postnatal malnutrition on the skin of newborn sucklings and lactating dams, collagen extractability with neutral salt in the newborns and their dams was found to decrease gradually according to the degree of malnutrition (Taniguchi et al. 1984). Prenatal protein-energy malnutrition, however, did not have the same effect on the skins of fetuses as it did on those of the dams, suggesting again that prenatal protein-energy malnutrition affects these skins differently from early postnatal protein-energy malnutrition.

When a chronically low-protein diet is given to young growing rats the collagen type I: type III ratio drops from $2 \cdot 1$ to $1 \cdot 3$, indicating a higher proportion of collagen type III in the skin (Deyl et al. 1981). Type III collagen is replaced by type I collagen as animals mature (Bailey \& Robins, 1972; Epstein, 1974), although during periods of rapid growth marked degradation of types I and III has been shown to occur to the same extent (Klein \& Chandrorajan, 1977). Since the ratio of type III:type I collagen for fetal skins did not differ between the groups, we conclude that malnutrition did not influence the rate of converting type III to type I collagen in the developing fetal skins. The higher type III collagen content in the dams' skins of the malnourished group suggests that protein-energy malnutrition during pregnancy may alter maternal skin metabolism to synthesize type III collagen through an unknown mechanism. Thus, the dams' skins might possible regress toward immaturity, as shown by the fact that newly synthesized collagen that appears to be immature is rich in type III collagen (Etherington \& Bailey, 1982).

The present study demonstrated that protein-energy malnutrition during pregnancy affects the various biochemical variables of the skin of fetuses and their dams, although in general dams' skins seem less affected than fetal skins. Thus, it becomes critical to be aware of the importance of proper nutrition during pregnancy for the development of fetal skins as well as, to a slightly lesser extent, the skins of their dams.

The authors acknowledge the assistance of Mr James Morris and Ms Gay Young, 
Department of Physiology. This study was in part supported by a grant from Orthopedic Research and Education Fund.

\section{REFERENCES}

Anasuya, A. \& Narasinga Rao, B. S. (1970). British Journal of Nutrition 24, 97-107.

Bailey, A. J. \& Robins, S. P. (1972). FEBS Letters 21, 350-354.

Bornstein, P. \& Piez, K. A. (1966). Biochemistry 5, 3460-3473.

Cabak, V., Dickerson, J. W. T. \& Widdowson, E. M. (1963). British Journal of Nutrition 17, 601-616.

Dawson, R. \& Milne, G. (1978). British Journal of Nutrition 39, 181-192.

Department of Health, Education and Welfare (1972). Ten State Nutrition Survey in the United States 1968-1970.

DHEW Publication no. (HSM) 72, pp. 8130-8134. Washington, DC: Department of Health, Education and Welfare.

Deyl, Z., Macek, K., Horakova, M. \& Adam, M. (1981). Physiologia Bohemoslovaca 30, 243-250.

Epstein, E. H. (1974). Journal of Biological Chemistry 249, 3225-3231.

Etherington, D. J. \& Bailey, A. J. (1982). Collagen Related Research 2, 307-322.

Gatt, R. \& Berman, E. R. (1966). Analytical Biochemistry 15, 167-171.

Jefferey, J. J., Dipetrillo, T., Counts, D. F. \& Catvoneo, K. R. (1985). Collagen Related Research 5, $157-165$.

Klein, L. \& Chandrorajan, J. (1977). Proceedings of the National Academy of Sciences, USA 78, 1436-1439.

Lowry, O. H., Rosebrough, N. J., Farr, A. L. \& Randall, R. J. (1951). Journal of Biological Chemistry 193, 267-275.

Miyahara, T., Murai, A., Tanaka, T., Shiozawa, S. \& Kaneyama, M. (1982). Journal of Gerentology 37, 651655.

Nakamoto, T., Porter, J. R. \& Winkler, M. M. (1983). British Journal of Nutrition 50, 75-80.

Nowak, T. S. \& Munro, H. N. (1977). Nutrition and the Brain, pp. 193-260 New York: Raven Press.

Shoji, H., Kimura, H., Miller, D. R. \& Nakamoto, T. (1983). Nutrition Research 3, 113-1 18.

Spray, C. M. \& Widdowson, E. M. (1950). British Journal of Nutrition 4, 332-353.

Sykes, B., Puddle, B., Francis, M. \& Smith, R. (1971). Biochemical and Biophysical Research Communications 43, 340-346.

Taniguchi, K., Shoji, H., Quinby, G. E. \& Nakamoto, T. (1984). Nutrition Research 4, 639-645.

Woessner, J. F. (1961). Archives of Biochemistry and Biophysics 93, 440-447.

Zeman, F. J. (1970). Journal of Nutrition 100, 530-538.

Zlatnik, F. J. \& Burmeister, L. F. (1983). American Journal of Obstetrics and Gynecology 146, 199-203. 